\title{
Undeclared Economy in Croatia during the 2004-2017 Period: Quarterly Estimates Using the MIMIC Method
}

\section{Josip Franić}

Institute of Public Finance, Zagreb, Croatia

josip.franic@ijf.hr
CroEconSur

Vol. 21

No. 1

June 2019

pp. 5-46

Received: September 6, 2018 Accepted: December 10, 2018 Research Article

doi:10.15179/ces.21.1.1

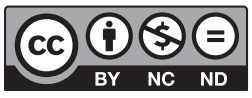

\section{Abstract}

Even though Croatia is among the most active EU countries when it comes to tackling undeclared economic activities, not much is known about the effectiveness of numerous policy measures introduced since joining the EU. As there is no systematic approach toward quantification of the undeclared economy in the newest member state, this paper fills the gap by presenting a tailored and robust procedure based on the Multiple Indicators and Multiple Causes (MIMIC) method. The methodology developed is then applied to assess the magnitude of the phenomenon in Croatia for the 2004-2017 period. The analysis reveals that the undeclared economy in Croatia has remained rather stable during the last decade and a half, with its value added ranging between 
HRK 24.1 and 26.9 billion. Accounting for 7.8 percent of the total GDP in 2017, undeclared undertakings represent a significant obstacle, which should therefore be systematically addressed. What is more, the findings indicate a rising trend, thus challenging the efficiency of the current policy approach by the Croatian government.

Keywords: undeclared economy, non-observed economy, MIMIC, labor input method, Croatia

JEL classification: E26, H26, H32, O17

\section{Introduction}

Croatia is one of the most active EU member states regarding the endeavors of the authorities to combat hidden economic activities (Baric \& Williams, 2013; Franic \& Williams, 2014; Ministry of Labour and Pension System, 2014). Introduction of fiscal cash registers, the reform of the tax system, the restructuring of the State Inspectorate, the introduction of vouchers in agriculture, and the statesupported professional training for inexperienced workers are just some of the numerous direct and indirect policies aimed at reducing non-compliance (Franic \& Williams, 2014).

Yet, to evaluate the effectiveness of such measures one needs to have an insight into the extent and dynamics of the activities tackled. However, there is no systematic and transparent approach toward the quantification of the phenomenon in Croatia. Sporadic studies on this matter date back to the pre-recession period, with their results being hardly comparable due to substantial differences in the scope of the analyzed activities (see Klarić, 2011; Lovrinčević, Mikulić, \& Nagyszombaty, 2011; Madžarević \& Mikulić, 1997; Nastav \& Bojnec, 2007). The interest in this topic has further diminished during the last decade, so no available longitudinal country-level assessment of this practice exists for the post- 
crisis period ${ }^{1}$. This paper aims to fill this gap by presenting and applying tailored methodology grounded on MIMIC modeling.

Before commencing, however, it is important to clearly define the activities of interest. Our main focus here will be on the issue of undeclared economy, which embraces all market-oriented productive activities of individuals and companies that are legal in their nature, but remain unreported to the authorities so as to evade taxes, to evade social security contributions, and/or to circumvent labor regulation (such as the legislation on minimum wage, maximum working hours, security standards etc.) or any other administrative requirement (European Commission, 2007). One can therefore see that this definition excludes illegal undertakings (e.g. prostitution, human trafficking, and drug smuggling), as well as self-provisioning, neighbor help, voluntary work, and other unpaid activities (Williams \& Franic, 2017)2.

The rest of the paper is organized as follows: after briefly presenting previous attempts to define, classify, and understand hidden economic activities, in Section 3 we describe the most popular methods for assessing their magnitude. This is followed by a detailed explanation and justification of the tailored procedure for quantifying undeclared economy in Croatia, which is given in Section 4. The estimated figures for value added by undeclared activities in the 2004-2017 period are provided in Section 5. Concluding remarks are given in the last part of the paper.

1 It should be mentioned that Croatia is regularly included in the MIMIC-based studies by Friedrich Schneider, who provides estimates for a range of countries (see Schneider, 2013, 2016b; Schneider, Buehn, \& Montenegro, 2010). However, simultaneous analysis of multiple countries requires a hardly plausible assumption about identical causes and nature of the phenomenon in all scrutinized economies. Indeed, numerous studies have shown that every country is unique when it comes to the set of factors underlying taxpayers' behavior, as well as regarding the effect of each individual determinant (Chen, 2005; Maloney, 2004; Torgler, 2011).

2 Undeclared economy thus represents a specific subpart of the non-observed economy, which refers to all productive activities that are not captured in the basic data sources used for compiling national accounts (OECD, 2002). 


\section{Hidden Economic Activities through the History - From the Informal Sector to the Undeclared Economy}

Even though the earliest studies on unrecorded economic activities can be traced back to the 1950s (see for instance Lewis, 1954), this issue came to the fore some 20 years later following the seminal work of the British anthropologist Keith Hart. The term "informal sector", which Hart coined in his study on the survival strategies of immigrants in Ghana (Hart, 1973), was later adopted and popularized by the International Labour Organization (ILO) (ILO, 1972, 1993, 1999). Defined as a set of "activities of the working poor who were working very hard but who were not recognized, recorded, protected or regulated by the public authorities" (ILO, 2002, p. 1), this phenomenon was believed to be only a shortterm disturbance inherent for developing countries. During this initial phase of research, the informal sector was therefore assumed to be a completely separate realm, which embraces solely individuals struggling to find a regular job (Hart, 1973; Sethuraman, 1976; Tokman, 1978).

However, it soon became obvious that such theories are far from reality. Alongside an increasing trend of deliberate tax evasion in developed countries, the studies conducted during the 1980s also revealed that the two parts of the economy (i.e. the official and the undeclared one) actually overlap to a substantial extent (Castells \& Portes, 1989; de Soto, 1989; Rakowski, 1994). Besides enhanced globalization and restrictive labor regulation, severe economic crisis in the late 1970s gave an additional boost to the development of unreported activities around the world. These novel insights motivated academics and experts to start seeking efficient strategies for tackling this detrimental economic and social phenomenon (Carr \& Chen, 2001; Davis, 2006).

Another turning point in this respect was the fall of socialist regimes across Europe. A substantial part of the population in these countries lost their job during the initial phase of transformation, thus being forced to rely on small- 
scale unreported activities (both legal and illegal) so as to survive (Hazans, 2005; Johnson, Kaufmann, \& Shleifer, 1997; Sedlenieks, 2003). This was accompanied by severe expansion of many other illegitimate practices, with corruption and string-pulling being the most prominent among them (Round, Williams, \& Rodgers, 2008; Sedlenieks, 2003; Woolfson, 2007).

Yet, after the onset of the global economic crisis in 2008, a particular emphasis was given to those hidden economic activities that are inherently legal and whose existence causes direct loses to the public budgets (Abdixhiku, Krasniqi, Pugh, \& Hashi, 2017; Hudson, Williams, Orviska, \& Nadin, 2012; Krasniqi \& Williams, 2017). In line with this, a range of international institutions have put the issue of the undeclared economy high on their agendas (Andrews, Caldera Sánchez, \& Johansson, 2011; Eurofound, 2013; European Commission, 2016a). Apart from financing research on the key drivers of the phenomenon, these institutions have also been intensively involved in developing strategies for reducing its magnitude (see Eurofound, 2008, 2013; European Commission, 2014, 2016b).

However, in order to evaluate whether a certain policy measure is efficient or not, it is essential to have a robust tool for monitoring the dynamics of undeclared activities over time. Yet, their quantification represents one of the most problematic tasks of the economic science. The next section provides a brief summary of the most popular estimation approaches, with particular emphasis regarding their advantages and limitations.

\section{Quantifying Non-Observed Economic Activities: An Overview of Available Methods}

According to the underlying approach, the existing strategies for estimating concealed economic activities can be roughly divided into three groups: direct methods, indirect methods, and model-based techniques (Klarić, 2011; Schneider $\&$ Buehn, 2016). Direct methods are concerned with the behavioral analysis of a selected sample of individuals, households and/or companies, whereby the findings 
are projected to the whole population (European Commission, 2014; Lazar, Moldovan, \& Pavel, 2008). This can be done either by conducting questionnaire surveys or by performing audits on tax returns. Unlike most indirect methods, this approach enables the quantification of any predetermined set of unreported activities, thus being suitable for analyzing the undeclared economy as a specific sphere inside the non-observed economy (European Commission, 2014).

However, direct methods are not of particular use for tracking the dynamics of hidden activities. For instance, differences between two waves of a questionnaire survey are to a greater extent the result of different sampling, and only partially an indicator of real changes within the population (Elgin \& Öztunali, 2012; Schneider \& Buehn, 2016). Also, survey respondents have a clear motivation to give faulty answers due to the illicit character of the practice (ILO, 2013). On the other hand, audits commonly encompass only those subjects that submitted tax returns, which leaves individuals and companies hiding all activities excluded from the analysis (Schneider \& Buehn, 2016). Direct methods hence can only give a lower boundary of the real state of affairs.

A further disadvantage of the direct approach can be found in a rather high implementation cost (Elgin \& Öztunali, 2012; ILO, 2013), which fostered scholars to develop cheap and efficient indirect techniques. Such methods are based on analyzing the trace that non-observed economic activities leave in the official statistics (European Commission, 2009; OECD, 2002). This is most commonly done by evaluating the dynamics of a smaller set (usually only one) of economic indicators.

The labor force participation approach, for instance, examines variations in the level of economic activity within a certain population, whereby every decrease in the activity rate compared to the baseline period (year or quarter) ${ }^{3}$ is attributed to the rise of unreported activities (Švec, 2009). Similarly, the currency demand approach is grounded on the assumption that any increase in demand for cash

3 This method requires either an implausible assumption about the non-existence of non-observed employment in the baseline period or an external estimate for this quarter/year. 
can be wholly attributable to the amplified activities within the non-observed part of the economy (Cagan, 1958; Pedersen, 2003). This method thus requires calculation of the cash-to-deposit ratio for the baseline period, which is then compared with subsequent periods so as to assess the magnitude of hidden activities (Tanzi, 1980).

The transaction approach, on the other hand, assumes there is a constant ratio of the volume of monetary transactions and the actual level of economic activity (Feige, 1989). Any increase in this ratio (compared to the baseline period) is hence believed to be a result of non-observed activities. Finally, the electricity consumption method assumes perfect elasticity between the consumption of electricity and official GDP (Kaufmann \& Kaliberda, 1996; Lacko, 1999). Growth of this ratio is thus also ascribed to non-observed activities and vice versa.

Despite their simplicity and low implementation cost, the enumerated indirect methods have limited practical value. First and foremost, they are not applicable for estimating the undeclared economy as this approach gives only summarized information about all non-observed activities (Feld \& Larsen, 2005; OECD, 2002). In addition, due to overly simplified assumptions, which are unlikely to hold true in reality, such methods generally overstate the actual magnitude of the non-observed economy (OECD, 2002; Schneider \& Buehn, 2016).

A more reliable indirect approach is based on analyzing the inconsistency between two different sources of information, whereby one of them is taken as credible and another is assumed to be flawed due to the existence of unreported activities. Most popular such methods are the evaluation of the discrepancy between national expenditure and income statistics and the evaluation of discrepancy between the survey on labor force participation and official employment data (European Commission, 2009, 2017; Istituto nazionale di statistica, 1993).

The latter approach, which is known as the labor input method, follows the assumption that the respondents of the labor force survey have no reason to 
hide their work status. This is because the survey is not concerned with the legal aspect of one's employment, i.e. whether they have a valid employment contract or not (European Commission, 2017). Since employers are expected to discard information about undeclared workers, the total number of workers in the official statistics will be smaller than suggested by the labor force survey. In line with this, figures from these two sources are compared (after certain adjustments) and the resulting difference is taken as an indicator of undeclared employment (Istituto nazionale di statistica, 1993). Using the assumption about identical productivity in the two spheres of the economy (i.e. official and undeclared), value added resulting from the undeclared economy can be easily calculated.

Unlike other indirect strategies, the labor input method assesses solely the undeclared economy (as defined earlier), which makes it one of the most reliable approaches for quantifying this specific group of activities (OECD, 2002). Indeed, the first official estimates of the added value resulting from the undeclared economy in the EU, published by the European Commission in 2017, are based on the labor input method (European Commission, 2017). The results of this study will be a starting point for our analysis, as explained below.

In this paper we follow the third estimation philosophy, i.e. the one residing on statistical modeling. The so-called MIMIC technique strives to assess the magnitude of the undeclared economy by extracting information from dynamics and interdependence of its multiple indicators and multiple causes (Barbosa, Pereira, \& Brandão, 2013; Dell'Anno, 2007; Schneider \& Buehn, 2016)4. The set of indicators and causes is determined from the existing research within the population of interest. Unlike indirect methods, which are commonly based on a single (predetermined) indicator or cause, MIMIC methodology thus provides a flexible interface for the development of a country-specific approach. Exactly this will be done for the case of Croatia. The next section therefore gives a detailed specification of the MIMIC method and explains the list of variables and procedures applied to assess the scope of the undeclared economy in Croatia.

4 An overview of recent studies applying MIMIC methodology to quantify unrecorded economic activities is given in Appendix 1. 


\section{Data and Methodology}

\subsection{MIMIC Models and Their Application to the Case of the Undeclared Economy}

Being a specific subtype of structural equation models, the MIMIC technique can be best described as a combination of linear regression and factor analysis (Dell'Anno, 2003; Ruge, 2010; Schneider, 2012). In addition to determining the level of association between measured variables, this approach is also highly useful if one wants to determine the characteristics of latent variables. Graphic illustration of a general MIMIC model with $q$ determinants and $p$ indicators is given in Figure 1.

Figure 1: An Illustration of a MIMIC Model with q Determinants and $p$ Indicators

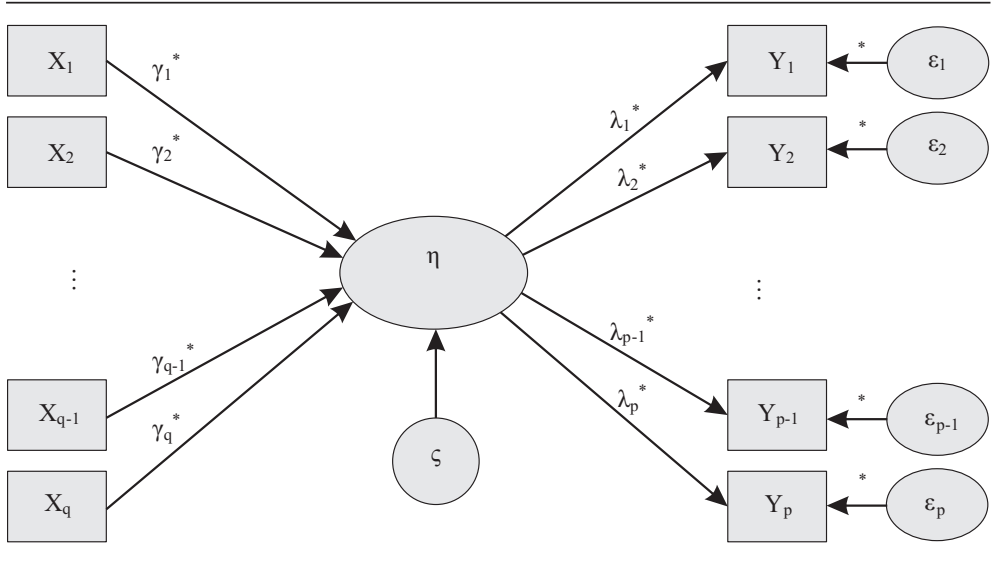

Source: Author's representation.

The variable of central interest is marked $\eta$ in the graph, arrows indicate the direction of causality, while asterisks denote model parameters. Rectangles represent measured (manifested) variables, while latent variables are illustrated as circles or ellipses. Random errors assigned to dependent variables are also portrayed as circles/ellipses since they are not directly measurable. 
In our specific case, this graph actually designates the following system of equations:

$$
\begin{gathered}
\eta=\gamma_{1} X_{1}+\gamma_{2} X_{2}+\ldots+\gamma_{q} X_{q}+\varsigma, \\
Y_{1}=\lambda_{1} \eta+\varepsilon_{1}, \\
Y_{2}=\lambda_{2} \eta+\varepsilon_{2}, \\
\quad \vdots \\
Y_{p}=\lambda_{p} \eta+\varepsilon_{p},
\end{gathered}
$$

where $\eta$ represents value added by the undeclared economy, $X_{1}-X_{q}$ are the determinants of undeclared activities, $Y_{1}-Y_{p}$ are indicator variables, $\gamma_{1}-\gamma_{q}$ and $\lambda_{1}-\lambda_{p}$ are model parameters, $\varepsilon_{1}-\varepsilon_{p}$ represent random errors assigned to indicators and $\varsigma$ is the error of the latent variable. Each error is assumed to be normally distributed (with the expected value 0 ) and independent of determinants of the variable it is assigned to.

Substituting the latent variable in equations (1)-(p) with the expression from (0) gives:

$$
\begin{gathered}
Y_{1}=\lambda_{1}\left(\sum_{i=1}^{q} \gamma_{i} X_{i}+\varsigma\right)+\varepsilon_{1}, \\
Y_{2}=\lambda_{2}\left(\sum_{i=1}^{q} \gamma_{i} X_{i}+\varsigma\right)+\varepsilon_{2}, \\
\vdots \\
Y_{p}=\lambda_{p}\left(\sum_{i=1}^{q} \gamma_{i} X_{i}+\varsigma\right)+\varepsilon_{p} .
\end{gathered}
$$

The system (1')-(p') now contains manifested variables only, which enables straightforward estimation of parameters. This is done by minimizing the difference between empirical covariance matrix and the covariance matrix implied by the model. The elements of the latter matrix are easily obtained taking into account the causal relationships between variables, as defined by the model. For instance, from the equation (j') and the definition of variance it follows that 
the variance of the indicator $Y_{j}$ (where $\mathrm{j}$ represents any value between 1 and $\mathrm{p}$ ) can be calculated as:

$$
\operatorname{Var}\left(Y_{j}\right)=\operatorname{Cov}\left(Y_{j}, Y_{j}\right)=\operatorname{Cov}\left(\lambda_{j}\left(\sum_{i}^{q} \gamma_{i} X_{i}+\varsigma\right)+\varepsilon_{j}, \lambda_{j}\left(\sum_{i}^{q} \gamma_{i} X_{i}+\varsigma\right)+\varepsilon_{j}\right) .
$$

Due to the assumed mutual independence of determinants, as well as the independence of each random error with other errors in the model and determinants, this expression is reduced to 5

$$
\begin{aligned}
\operatorname{Var}\left(Y_{j}\right) & =\sum_{i=1}^{q} \operatorname{Cov}\left(\lambda_{j} \gamma_{i} X_{i}, \lambda_{j} \gamma_{i} X_{i}\right)+\operatorname{Cov}(\varsigma, \varsigma)+\operatorname{Cov}\left(\varepsilon_{j}, \varepsilon_{j}\right) \\
& =\lambda_{j}^{2} \sum_{i=1}^{q} \gamma_{i}^{2} \operatorname{Var}(X)_{i}+\xi^{2}+\sigma_{j}^{2},
\end{aligned}
$$

where $\sigma_{j}^{2}$ designates the variance of a random variable $\varepsilon_{j}$, $\xi^{2}$ is a variance of the latent variable error, while $\lambda_{j}$ and $\gamma_{i}$ represent model parameters.

The same procedure gives covariance between determinants and indicators, as well as covariance between two indicators. For instance, covariance between determinant $X_{i}$ and indicator $Y_{j}$ is:

$$
\begin{aligned}
\operatorname{Cov}\left(X_{i}, Y_{j}\right) & =\operatorname{Cov}\left(X_{i}, \lambda_{j}\left(\sum_{i}^{q} \gamma_{i} X_{i}+\varsigma\right)+\varepsilon_{j}\right) \\
& =\operatorname{Cov}\left(X_{i}, \lambda_{j} \gamma_{i} X_{i}\right)=\lambda_{j} \gamma_{i} \operatorname{Var}\left(X_{i}\right) .
\end{aligned}
$$

On the other hand, covariance between indicators $Y_{j}$ and $Y_{k}(j \neq k)$ is equal to:

$$
\begin{aligned}
\operatorname{Cov}\left(Y_{j}, Y_{k}\right) & =\operatorname{Cov}\left(\lambda_{j}\left(\sum_{i}^{q} \gamma_{i} X_{i}+\varsigma\right)+\varepsilon_{j}, \lambda_{k}\left(\sum_{i}^{q} \gamma_{i} X_{i}+\varsigma\right)+\varepsilon_{k}\right) \\
& =\lambda_{j} \lambda_{k} \sum_{i=1}^{q} \gamma_{i}^{2} \operatorname{Var}(X)_{i}+\xi^{2} .
\end{aligned}
$$

5 For an overview of the statistical features related to variance and covariance, see Raykov \& Marcoulides (2006). 
The assumed equivalence of variances and covariances obtained this way with their empirical counterparts gives a set of $\frac{p(p+2 q)+1}{2}$ equations $^{6}$. The problem is thus reduced to finding model parameters which minimize the total discrepancy between left-hand and right-hand sides of these equations. Maximum likelihood procedure is the most common approach for doing so, but alternative strategies are also available in cases when input variables are not normally distributed.

After obtaining model parameters, it is essential to assess to what extent the model approximates data. This is done by evaluating a battery of tests and indices that provide information on the inconsistency between the empirical covariance matrix and the one implied by the estimated parameters. The most common such statistics are chi-square, Root Mean Square Error of Approximation (RMSEA), Comparative Fit Index (CFI), Standardized Root Mean Square Residual (SRMR), and Coefficient of Determination (CD) .

It is important to realize that MIMIC modeling is confirmative in its nature, given that the post-estimation starts from the hypothesis that the model sufficiently approximates data. The model is deemed inappropriate only if there is enough evidence to reject the null-hypothesis. The failure to discard it therefore does not mean that the model is satisfactory, nor that there is no better model (Kline, 2011; Raykov \& Marcoulides, 2006). Indeed, it is common to have a whole set of models that equally well describe the relationship between the observed variables. For this reason, the most common approach is to define several models and to choose the best one after comparing the accompanying statistical indices (Raykov \& Marcoulides, 2006). Exactly this strategy will be applied here, as discussed later. Before that, it is important to describe and justify the choice of input variables.

6 The total number of elements in both matrices is $\frac{(p+q)(p+q-1)}{2}$. However, due to assumed mutual independence of determinants, the total of $\frac{q(q+1)}{2}$ elements are excluded from the system.

7 For the exact definition and explanation of these statistics, see Kline (2011). 


\subsection{List of Input Variables}

Recent research studies on undeclared activities in Croatia identified a weak psychological contract between the state and citizens as the essential driver of non-compliance, alongside tax burden and unemployment (Baric \& Williams, 2013; Franic \& Williams, 2014; Williams \& Franic, 2017). Accordingly, variables quantifying the trustworthiness of the authorities and the perception of citizens in this respect were of particular interest when developing our model.

However, the choice of input variables was strongly influenced by sensitivity of the MIMIC method to sample size. A short range of available macroeconomic data, which is the result of Croatia gaining its independence quite recently, is additionally restricted due to frequent changes in the measurement methodology. Since for the majority of plausible determinants comparable time series are limited to the period after 2004, the analysis of quarterly data was the only feasible option. Yet, this significantly reduced the potential set of input variables, as most macroeconomic data in Croatia are given on an annual basis only.

Despite limited availability of quarterly data, three variables that can help in conceptualizing the invisible contract between the state and taxpayers were identified. The first and the most straightforward one is the average rating of the government, which was taken from the CRO Demoskop survey ${ }^{8}$. It is expected that the greater confidence in the work of the government will result in a reduction of undeclared activities, and therefore we anticipate a negative sign of the estimated coefficient.

Another important variable in this respect is the one measuring direct expenditure from the public budgets (both local and central) for employees (CNB, 2018b). This variable serves as a proxy for the number of employees in the public sector, as the exact figures are not publicly available. Negative effect of this variable is

8 Each participant in this monthly survey encompassing 1,300 citizens is asked to evaluate the work of the government on the scale from 1 to 5 . For the purpose of our analysis, average grades for the last month in a particular quarter are used. The data for the 2004-2008 period were obtained from the Promocija Plus Agency, while the remaining figures were taken from media reports. 
envisaged, given that an increase in expenditure for public sector employees is expected to reduce citizens' willingness to finance the system.

Social welfare expenditure is yet another potential driver of non-compliant behavior in Croatia, as it also has a lot to do with the invisible contract between the state and citizens (CNB, 2018b). Nevertheless, the effect of this variable is not easy to predict. On the one hand, increased income from the public budget improves the financial situation of the poor, therefore reducing their need to seek alternative sources of revenue (Krasniqi \& Williams, 2017). Also, more generous social policy creates an impression that the state takes care of the most vulnerable members of society, which may increase citizens' tax morale.

On the other hand, since entitlement for many social benefits is dependent on income, the recipients of such benefits often have a clear motivation to hide their earnings in order to maintain the privilege. Moreover, in countries with inefficient social protection, a significant portion of such funds ends up in the hands of individuals who do not really need them. This can provoke the revolt of compliant citizens who essentially finance the lifestyle of such deceivers.

In order to assess the demand side of the undeclared economy, the average monthly net wage is also included as a potential determinant (CNB, 2018b). Yet, the sign of a causal relationship in this case is also hard to predict. On the one hand, an upsurge of the disposable income is expected to decrease one's reliance on cost-reducing strategies, whereby the payment of goods and services "under the table" is the most common of such strategies. However, in societies where significant distrust in authorities leads to undeclared work "out of defiance", an increase in disposable income actually means more resources that an individual can spend within the undeclared sphere of the economy. Since research studies suggest that the latter is the case in Croatia (Franic \& Williams, 2017; Williams $\&$ Franic, 2017), we expect that larger average net wage will ultimately result in the increased volume of the undeclared economy. 
Finally, to account for the role of tax burden, the total revenue of the consolidated government from taxes and social contributions is also taken as one potential determinant (CNB, 2018b). Also, the effect of unemployment is accounted for by including the total number of unemployed individuals in the register of the Croatian Employment Service (CES) (CES, 2018).

Gross domestic product and the amount of cash in circulation are most commonly used indicator variables in MIMIC estimates of the undeclared economy (Dell'Anno, 2003; Klarić, 2011; Tedds, 2004). This paper makes no exception in this respect. For the purpose of our analysis, we use Eurostat data on quarterly GDP (Eurostat, 2018), while the figures for cash in circulation are taken from the balance sheet of the Croatian National Bank (CNB) (CNB, 2018a).

The initial set of variables therefore consists of six determinants and two indicators. Before proceeding with the analysis, it was necessary to transform the data so as to achieve satisfactory statistical properties. First of all, monetary variables were deflated using the 2010 price index (Eurostat, 2018) and seasonal components were removed where needed'. The last step was to address the issue of stationarity, which was found in all input variables (see Appendix 2). As the standard approach with differencing did not solve the problem, the most plausible solution was to model growth rates. For each of the eight input variables, quarterly growth rates were thus defined as:

$\Delta X_{t}=\frac{X_{t}-X_{t-1}}{X_{t-1}}$

In addition to fixing the non-stationarity issues, this transformation also resolved the question regarding the interpretation of the latent variable. Namely, as all input variables undergo the same set of adjusting procedures, it is clear that

9 The rating of the government was the only variable without seasonal variations. The seasonal effect detected in the remaining variables was removed following the TRAMO/SEATS procedure. 
the latent variable will have the same form ${ }^{10}$. Its values will therefore represent quarterly growth rates of the real seasonally adjusted value added resulting from undeclared activities ${ }^{11}$.

The decision to evaluate growth rates instead of raw values acknowledges yet another important limitation of the MIMIC models. Namely, this method can only analyze the dynamics of the observed phenomenon, while for its actual magnitude one needs to take an external estimate as a starting point ${ }^{12}$ (Breusch, 2005b). By defining the latent variable in terms of the growth rates, we therefore clearly indicate the exact role of the MIMIC modeling in the process.

Finally, and most importantly, this approach also enables us to circumvent the controversial calibration procedure ${ }^{13}$. In this paper we chose to set up the variance of the latent variable rather than one of the model parameters. The most logical and theoretically convenient option was to assume equal dynamics of the activities within both spheres of the economy (i.e. official and undeclared). In other words, the variance of the growth rate of the undeclared economy is assumed to be equal to the variance of the growth rate of the official GDP. Since the plausibility of this assumption cannot be verified in practice, it is vital to analyze its impact on final estimates. This will be done in the next section,

10 Since the features of the latent variable are grasped from its determinants and indicators, identical treatment of input variables removes the possibility for subjective interpretation of the final results (see Breusch, 2005a). It should, however, be mentioned that the growth rates of unemployment had to be differentiated to achieve stationarity (see Appendix 2). Nevertheless, the differentiation of a single determinant does not influence the remaining model parameters and therefore this transformation did not undermine the credibility of the model.

11 Yet, this approach did not address the issue of deviation from normal distribution, which was found in most input variables. As the standard procedure based on the maximum likelihood approach would require further transformation of variables (thus re-opening the question related to the interpretation of the latent variable), the decision was made to proceed with the weighted least square procedure, which does not require normal distribution.

12 The latent variable's unit of measurement is not a priory defined (as it is not directly measurable by its nature), and therefore it is essential to make certain assumptions about the probability distribution of this variable or the relation to manifest variables. Both approaches require an external estimate for a baseline period, as will be explained later (see also Schneider et al., 2010).

13 Calibration assumes fixating the coefficient assigned to one of the indicators (Breusch, 2005a; Schneider et al., 2010). Since this affects all other parameters of the model, this strategy effectively gives estimates of the "latent index". The index needs to be transformed using one or more external estimates of the phenomenon of interest. This is done by multiplying all values of the obtained "index" with the ratio of the external estimate and the value of the index in a baseline period. 
alongside the comparison of our results with those obtained when the calibration procedure is used.

Before moving to the results, it is important to justify the choice of the external estimate for the undeclared economy, which is necessary to transform the obtained growth rates into absolute amounts (see Appendix 3). For this purpose, we use the estimates by the European Commission based on the labor input method, as this is the only relevant source of information on the matter in Croatia referring to the post-crisis period (European Commission, 2017). According to the study, undeclared economy in Croatia accounted for 17.1 percent of the official GDP in 2013. This would say that such activities created HRK 24.45 billion of value added, which is therefore the quantity used as a starting point in our analysis.

\section{Findings}

The results of the MIMIC analysis shown in Table 1 reveal that the initial model with six determinants and two indicators approximates the data quite well. Alongside a rather low and insignificant value of $\chi^{2}$, all remaining indices also favor the model. However, only three out of six determinants are statistically significant. Since there is no reason to keep insignificant variables, it was necessary to re-specify the model. In the second step, six additional models were therefore constructed, whereby a single determinant is excluded from each of them. This was done because the omission of a single variable can have a substantial effect on all remaining coefficients, owing to their mutual interdependence, which was not accounted for in the model. 


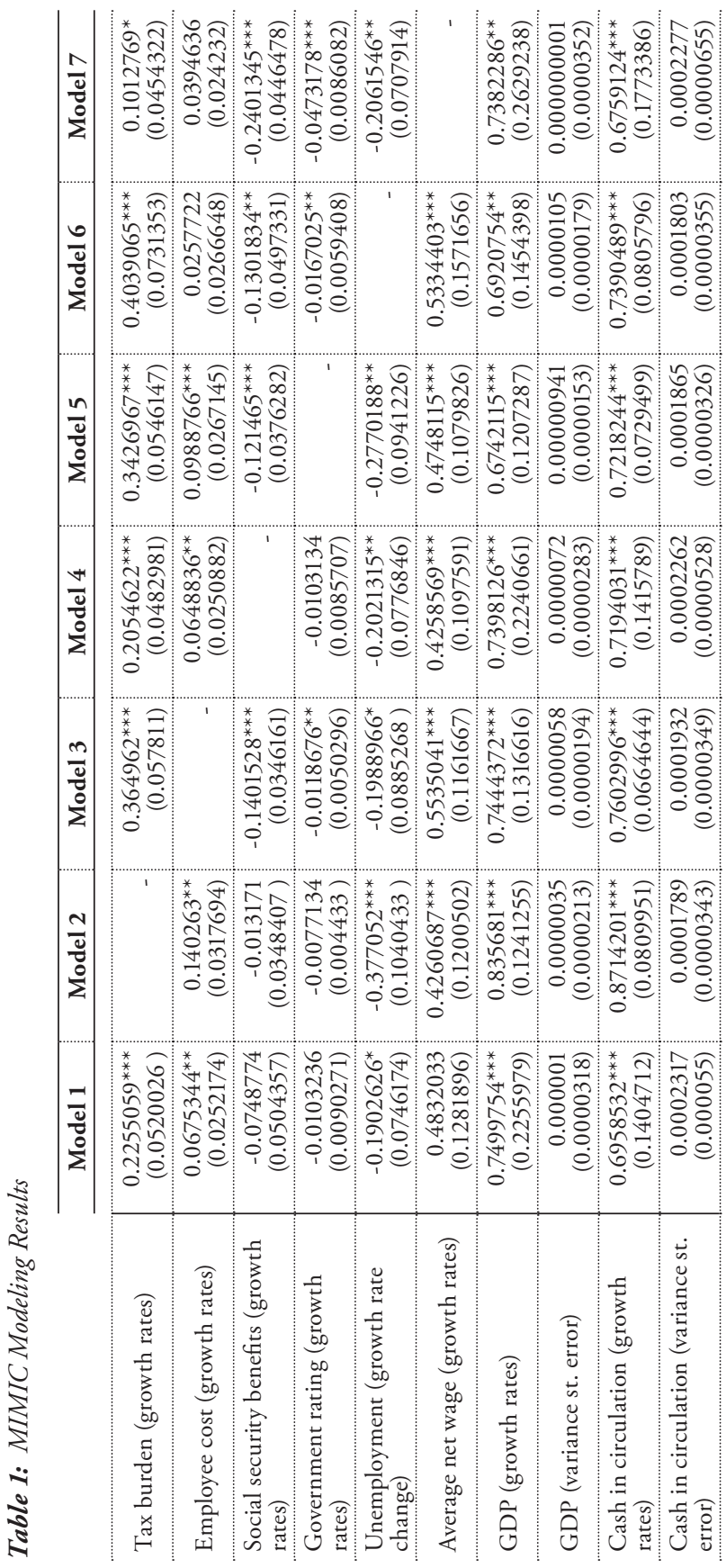




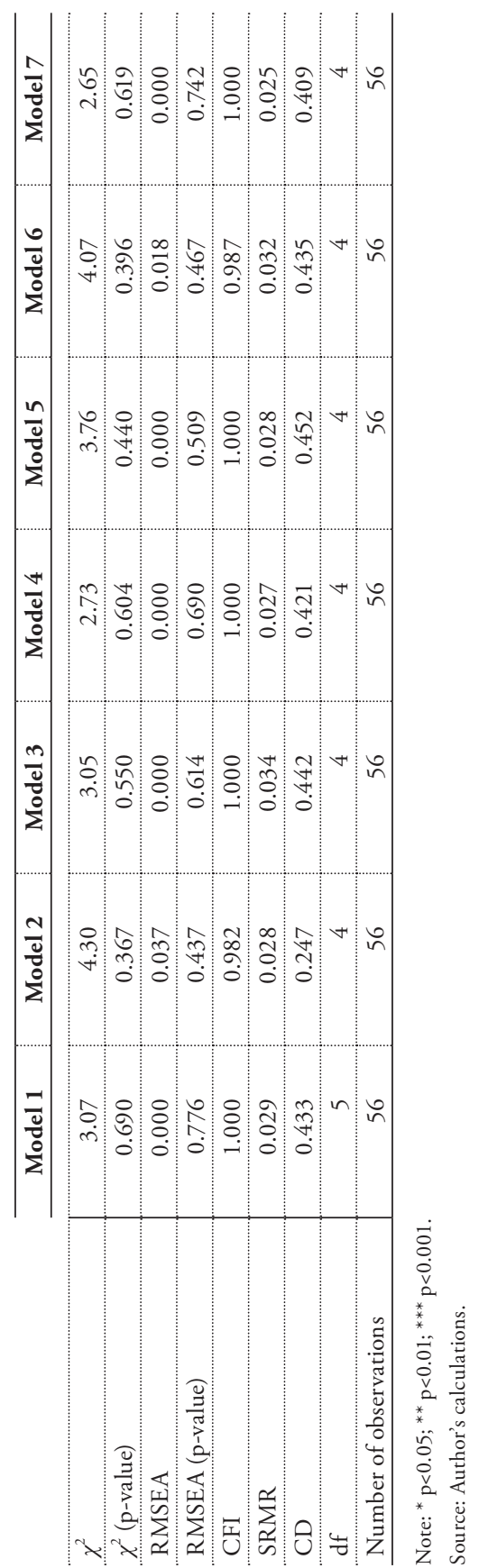


As can be noticed from Table 1, all six models pass the $\chi^{2}$ test. However, only models 3 and 5 have all five determinants significant, so they were preferred over the remaining ones. Since both these models have similar diagnostics, the decision made was to retain model 3 due to a somewhat lower value of the $\chi^{2}$ test statistic.

Before presenting the estimates of the undeclared economy in Croatia based on the chosen model, it is important to point out unexpected findings regarding the impact of unemployment. The accompanying coefficient takes negative values in all models, which means that increased unemployment entails a reduction of the undeclared economy. This may suggest that employed individuals are actually the main stakeholders in the undeclared economy, either through underreporting of salaries, afternoon moonlighting or through the demand for such products and services. Indeed, this assumption is further reinforced by obtaining positive coefficients of the average net salary in all models. When it comes to other determinants, one can see that the effects of tax burden and government rating are as expected. Finally, increased expenditure on social benefits is found to reduce the occurrence of undeclared activities.

The estimated monetary contribution of the undeclared economy, which is presented in Figure 2, reveals that such activities accounted for HRK 5.5 and 7.5 billion during the observed period ${ }^{14}$. The raising trend of undeclared practices prior to the economic downturn was followed by a slight decline after 2009. Another interesting thing to point out is a change in the dynamics of the undeclared economy after the outbreak of the economic crisis, as the existing differences in the occurrence of these activities between the summer and winter periods were additionally augmented after 2009. 
Figure 2: Estimated Value Added by the Undeclared Economy in Croatia for the 2004-2017 Period (Real Values per Quarter), in HRK Million

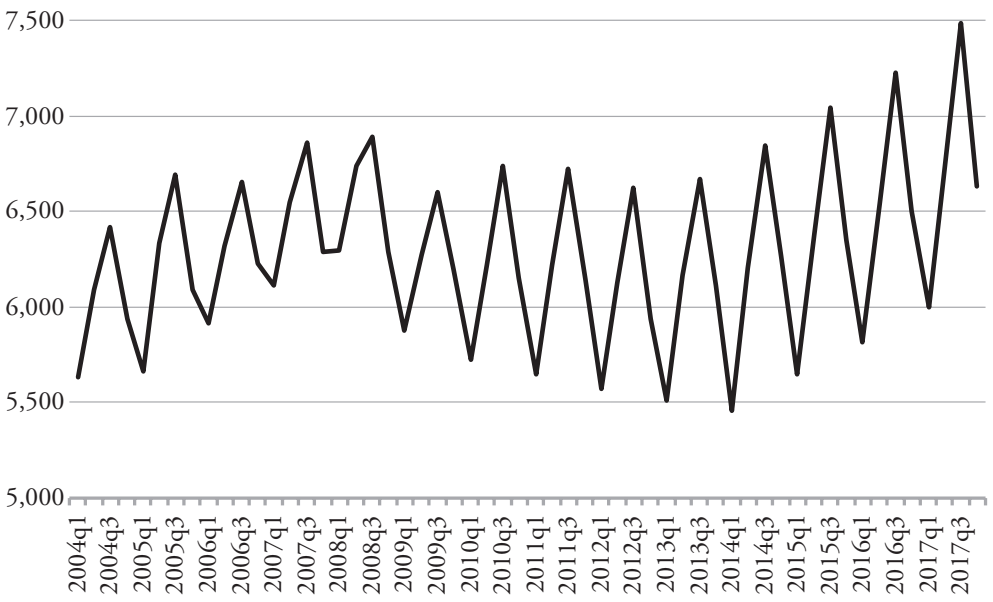

Source: Author's calculations.

Figure 3: Undeclared Economy in Croatia on an Annual Basis during the 2004-2017 Period, in HRK Million and as \% of GDP

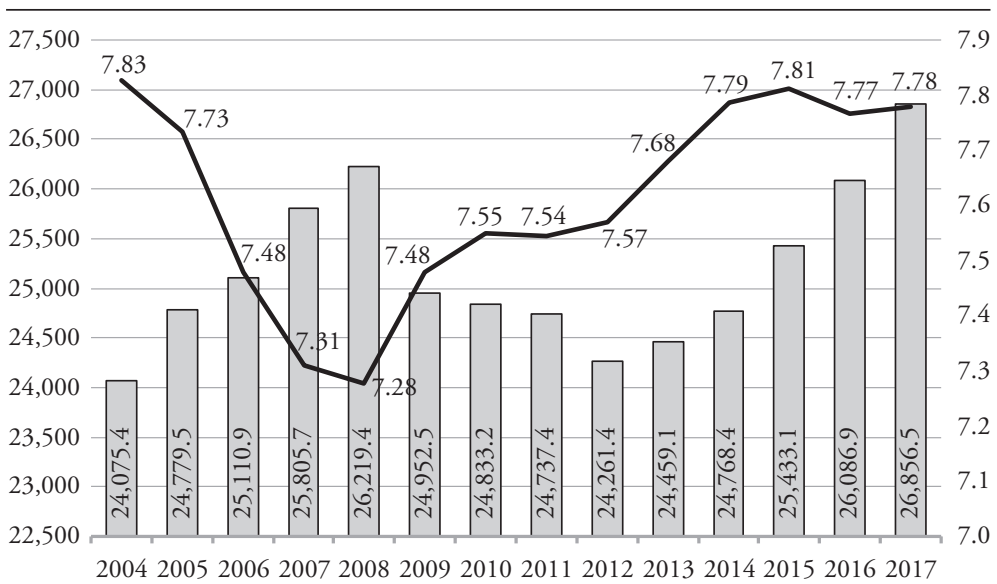

$\square$ Value added by the undeclared economy in million HRK, real values (left axis)

-Undeclared economy as \% of official GDP (right axis)

Source: Author's calculations. 
Yet, there is evidence of increased activities within the undeclared sphere after 2013, which challenges the effectiveness of numerous policy measures introduced by the Croatian government since joining the EU. This can be further verified by an insight into value added by the undeclared economy on a yearly basis, which is given in Figure 3. After falling to HRK 24.3 billion in 2012, this part of the economy has been growing over the next four years up to HRK 26.9 billion in 2017. The volume of the undeclared economy is therefore much above its pre-crisis level, which undoubtedly calls for a more systematic approach toward combating this phenomenon.

\subsection{Robustness Check}

To analyze the effect of the central assumption about equal variability within the two spheres of the economy, six additional models with the same determinants and indicators were constructed. In three models, larger variance of undeclared activities is assumed $(1.25,1.50$, and 1.75 of the variance of the GDP growth rate, respectively), while the remaining three assumed lower variability at the same percentage shift. Figure 4 compares the results of the six supplementary models with those from the chosen one.

As can be seen, all seven models indicate a similar trend up to mid-2014, after which substantial discrepancy is noticeable. While models with assumed higher variability of the undeclared sphere point to the rise of its share after the third quarter of 2014, those assuming lower variability indicate a decline in this respect. The comparison of the results therefore implies lower reliability of the estimated values for the last three analyzed years. 
Figure 4: Estimated Share of the Undeclared Economy in GDP Depending on the Assumed Variance

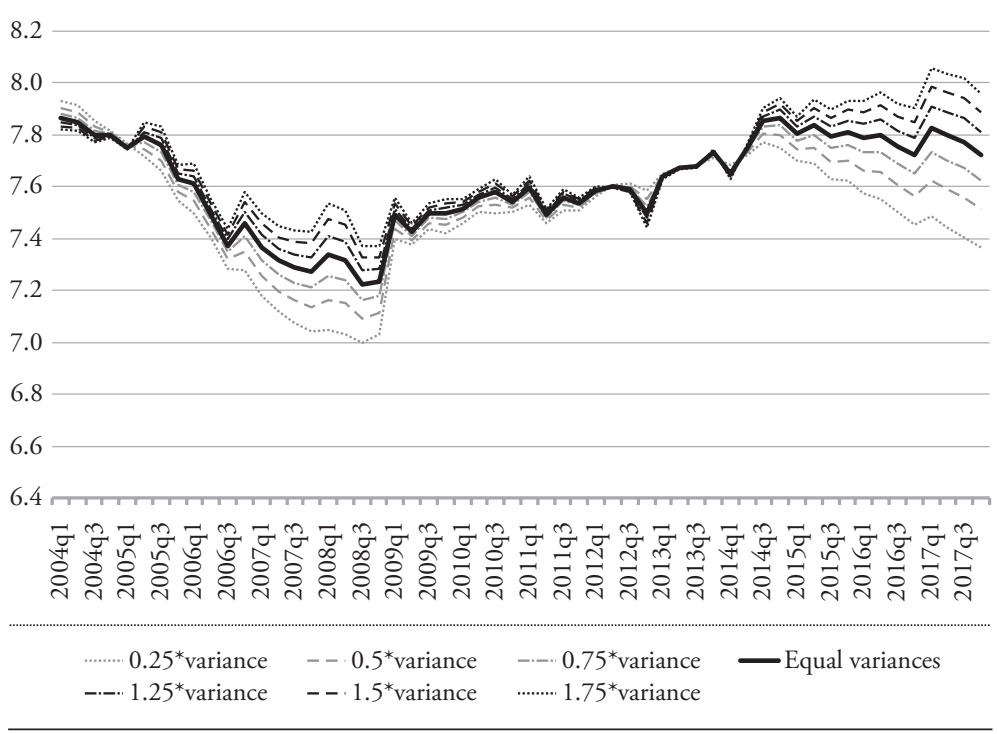

Source: Author's calculations.

Slight discrepancy is also noticeable for the period between the last quarter of 2006 and the last quarter of 2008, but in this case trends coincide. Regardless of these inconsistencies between the seven observed models, differences in estimated values are not so drastic. For example, while the maximum estimated share of the undeclared economy for the last quarter of 2017 is 7.96 percent, the minimum estimate is only 0.59 percentage points lower, accounting for 7.37 percent. Similarly, for the first quarter of 2008, the estimated shares range from a minimum of 7.05 percent to a maximum of 7.54 percent. Taking into account the fact that no significant differences between models are noticeable for remaining periods, it can be concluded that the assumption of the identical dynamics within the two spheres of economy did not significantly affect the credibility of the estimates. 
Figure 5: Comparison of the Obtained Results with Those When the Standard Procedure with Calibration is Applied

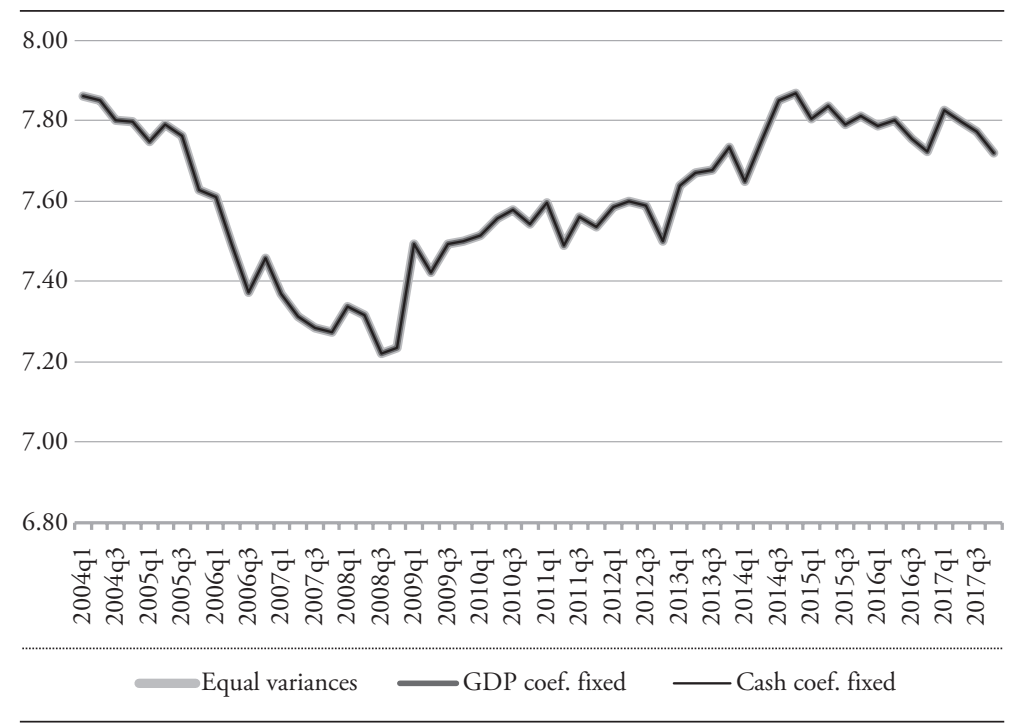

Source: Author's calculations.

To further examine the robustness of the model, Figure 5 compares the results of our analysis with those of the standard approach with calibration. As can be seen, the results are identical in all three cases, thus implying that the final outcome is completely independent of the chosen strategy.

To clarify the equivalence of these approaches, Table 2 compares the results of the MIMIC models for each of them. In all three cases the coefficients assigned to the determinants and indicators are significant with identical p-values. The only difference appears in the absolute values of these coefficients, even though their mutual ratio is equal (see columns 5 and 6 in the table). This is because constraining the coefficient next to one of the indicators will result in contraction (or expansion) of the latent variable for the ratio of the "actual value" and the constrained value of a coefficient pertaining to that particular indicator. This will cause a reverse proportional change in the coefficients assigned to the causal variables. 
Table 2: Comparison of the Three Alternative MIMIC Models

\begin{tabular}{|c|c|c|c|c|c|}
\hline & $\begin{array}{c}\text { A-chosen } \\
\text { model (equal } \\
\text { variances) }\end{array}$ & $\begin{array}{l}\text { B - GDP coef. } \\
\text { fixed }\end{array}$ & $\begin{array}{l}\mathrm{C}-\text { cash coef. } \\
\text { fixed }\end{array}$ & A/B & $\mathrm{A} / \mathrm{C}$ \\
\hline $\begin{array}{l}\text { Tax burden (growth } \\
\text { rates) }\end{array}$ & $\begin{array}{r}0.364962^{* * *} \\
(0.057811)\end{array}$ & $\begin{array}{r}0.2716913^{* * *} \\
(0.035843)\end{array}$ & $\begin{array}{r}0.2774804 \\
(0.0389064)\end{array}$ & 1.3434 & 1.3153 \\
\hline $\begin{array}{l}\text { Social security } \\
\text { benefits (growth } \\
\text { rates) }\end{array}$ & $\begin{array}{r}-0.1401528^{* * *} \\
(0.0346161)\end{array}$ & $\begin{array}{r}-0.104335^{* * *} \\
(0.0294317)\end{array}$ & $\begin{array}{r}-0.1065581^{* * *} \\
(0.0262737)\end{array}$ & 1.3434 & 1.3153 \\
\hline $\begin{array}{l}\text { Government rating } \\
\text { (growth rates) }\end{array}$ & $\begin{array}{r}-0.0118676^{* *} \\
(0.0050296)\end{array}$ & $\begin{array}{r}-0.0088347^{* *} \\
(0.0032921)\end{array}$ & $\begin{array}{r}-0.0090229^{* *} \\
(0.00368)\end{array}$ & 1.3434 & 1.3153 \\
\hline $\begin{array}{l}\text { Unemployment } \\
\text { (growth rate change) }\end{array}$ & $\begin{array}{l}-0.1988966^{*} \\
(0.0885268)\end{array}$ & $\begin{array}{l}-0.148066^{*} \\
(0.0763126)\end{array}$ & $\begin{array}{r}-0,151221^{*} \\
(0.0667178)\end{array}$ & 1.3434 & 1.3153 \\
\hline $\begin{array}{l}\text { Average net wage } \\
\text { (growth rates) }\end{array}$ & $\begin{array}{r}0.5535041^{* * *} \\
(0.1161667)\end{array}$ & $\begin{array}{r}0.4120491^{* * *} \\
(0.0996361)\end{array}$ & $\begin{array}{r}0.420829^{* * *} \\
(0.0828029)\end{array}$ & 1.3434 & 1.3153 \\
\hline GDP (growth rates) & $\begin{array}{r}0.7444372^{* * *} \\
(0.1316616)\end{array}$ & 1 & $\begin{array}{r}0,9791367^{* * *} \\
(0.1751841)\end{array}$ & 0.7444 & 0.7603 \\
\hline $\begin{array}{l}\text { Cash in circulation } \\
\text { (growth rates) }\end{array}$ & $\begin{array}{r}0.7602996^{* * *} \\
(0.0664644)\end{array}$ & $\begin{array}{l}1.021308^{* * *} \\
(0.1827292)\end{array}$ & 1 & 0.7444 & 0.7603 \\
\hline $\begin{array}{l}\text { GDP (variance st. } \\
\text { error) }\end{array}$ & $\begin{array}{r}0.0000058 \\
(0.0000194)\end{array}$ & $\begin{array}{r}0.0000058 \\
(0.0000194)\end{array}$ & $\begin{array}{r}0.0000058 \\
(0.0000194)\end{array}$ & 1 & 1 \\
\hline $\begin{array}{l}\text { Cash in circulation } \\
\text { (variance st. error) }\end{array}$ & $\begin{array}{r}0.0001932 \\
(0.0000349)\end{array}$ & $\begin{array}{r}0.0001932 \\
(0.0000349)\end{array}$ & $\begin{array}{r}0.0001932 \\
(0.0000349)\end{array}$ & 1 & 1 \\
\hline $\begin{array}{l}\text { Undeclared economy } \\
\text { (variance st. error) }\end{array}$ & 0.0001335897 & $\begin{array}{r}0.000074 \\
(0.0000262)\end{array}$ & $\begin{array}{r}0.0000772 \\
(0.0000135)\end{array}$ & 1.8053 & 1.7304 \\
\hline$\chi^{2}+\cdots$ & 3.05 & 3.05 & 3.05 & 1 & 1 \\
\hline$\chi^{2}(\mathrm{p}$-value $)$ & 0.550 & 0.550 & 0.550 & 1 & 1 \\
\hline RMSEA & 0.000 & 0.000 & 0.000 & 1 & 1 \\
\hline RMSEA (p-value) & 0.614 & 0.614 & 0.614 & 1 & 1 \\
\hline CFI & 1.000 & 1.000 & 1.000 & 1 & 1 \\
\hline SRMR & 0.034 & 0.034 & 0.034 & 1 & 1 \\
\hline $\mathrm{CD}$ & 0.442 & 0.442 & 0.442 & 1 & 1 \\
\hline $\mathrm{df}$ & 4 & 4 & 4 & 1 & 1 \\
\hline $\begin{array}{l}\text { Number of } \\
\text { observations }\end{array}$ & 56 & 56 & 56 & 56 & 56 \\
\hline
\end{tabular}

Source: Author's calculations. 


\section{Conclusion}

This paper presented a tailored approach for estimating the undeclared economy in Croatia, which is based on the MIMIC modeling. The developed methodology was then applied to estimate the magnitude of the phenomenon on a quarterly basis for the 2004-2017 period. The results indicate a relatively stable share of undeclared economy in total GDP. During the last decade and a half, such activities accounted for between 7.3 percent and 7.8 percent of GDP, with the added value of this part of the economy ranging between HRK 24.1 and 26.9 billion. Despite small variations on an annual basis, there are significant deviations within a year. Activities staying under the radar of the authorities are much more frequent in the summer period, while their minimum is regularly achieved in the first trimester.

The estimated figures for the undeclared economy in Croatia represent the most important, but certainly not the only contribution of this research article. Its practical significance is above all reflected in exposing an increased trend of undeclared activities after 2013, which questions the effectiveness of the current policy approach by the Croatian government. In line with the presented results, there seems to be a need to switch from widely predominant preventive and coercive measures, which have been used thus far, to indirect policy strategies seeking to improve the psychological contract between the state and citizens.

An additional contribution of this study can be found in every single step of the analysis being described and justified in detail, which will enable other researchers and experts in Croatia to straightforwardly replicate the study. It is therefore hoped that this paper will lay the foundations for systematic monitoring of the phenomenon in the newest EU member state. Yet, researchers from elsewhere will find the presented technical account of the applied methodology highly beneficial as well, since it can be easily adapted to other countries. In fact, if this paper stimulates further developments in this research field, then it will fulfill its broader aim. 
However, it should be stressed that in spite of all steps taken to increase the credibility of the estimates, there is still room for improvement. First of all, the resulting figures most likely understate the real extent of the phenomenon. Alongside the limited capability of the labor input method to fully grasp certain types of undeclared activities (e.g. underreporting of employees' wages, sporadic work and income from undertakings related to hobbies), an additional problem lies in the unlikely assumption of their absolute absence from the public sector. Given this, the figures provided here should be perceived only as the best available proxies for the undeclared economy in Croatia.

A further issue relates to a considerable lack of quarterly data, which resulted in many potentially important determinants of this practice not being taken into account. The most obvious examples are tax morale, trust in institutions, pervasiveness of corruption, capabilities of the tax authorities to detect perpetrators, and the efficiency of the judiciary system. It is thus of vital importance to enhance the quantity and quality of economic, socio-demographic and administrative data in Croatia in order to increase the credibility of similar studies in future.

Yet, the most important limitation can be found in the MIMIC model's oversimplification of complex associations between the analyzed variables. For instance, there is by no means a strong mutual interdependence between the formal and undeclared economy, but this cannot be captured within the existing MIMIC model. This issue is additionally augmented by reliance on covariance analysis, which essentially blurs the real direction of one-way causality implied by the MIMIC model.

Finally, there is certainly a whole range of other factors simultaneously affecting both spheres of the economy. Unfortunately, the inclusion of a greater number of variables and links between them is not possible at the moment due to technical limitations of this statistical procedure. However, it is certain that continual progress in the field of statistics will make such analyses more credible in the future than they are now. 


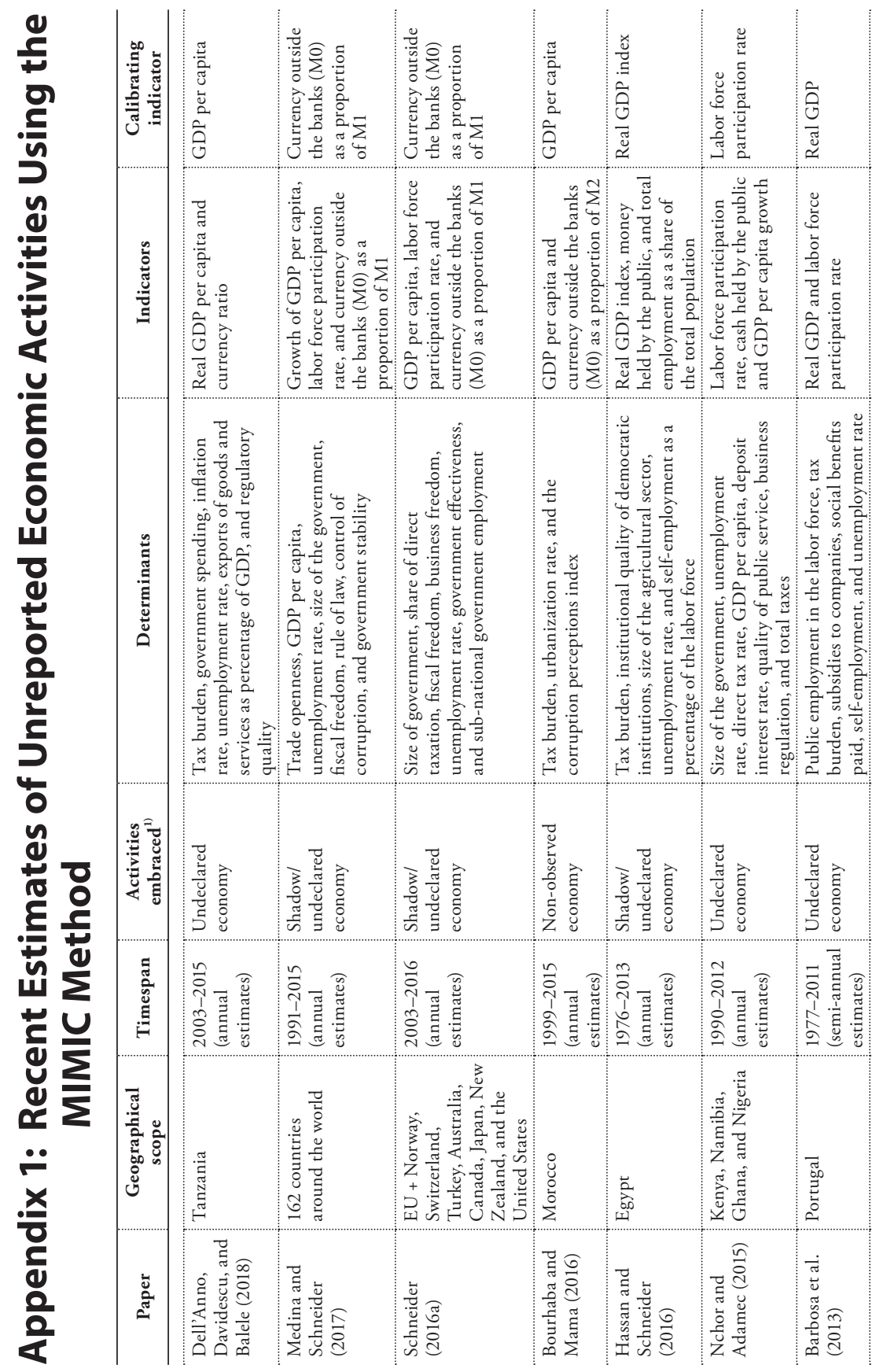




\begin{tabular}{|c|c|c|c|c|}
\hline 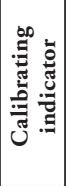 & : & 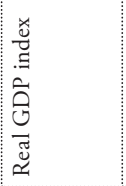 & $\frac{\tilde{O}}{\mathscr{J}}$ & 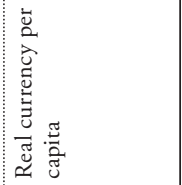 \\
\hline 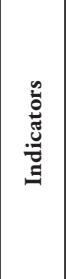 & 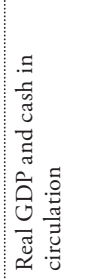 & 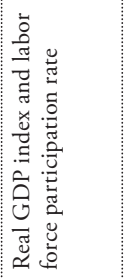 & 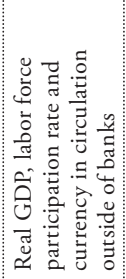 & 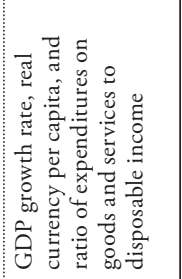 \\
\hline 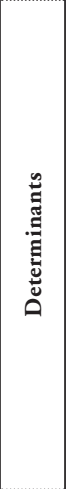 & 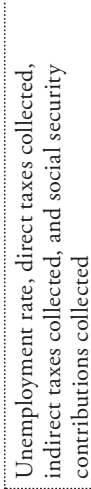 & 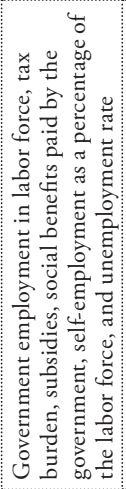 & 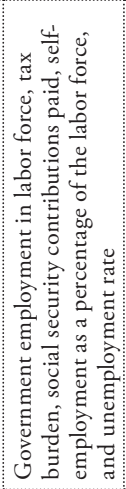 & 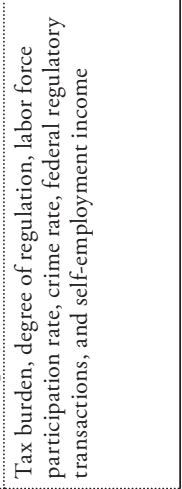 \\
\hline 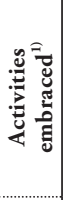 & 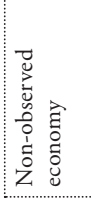 & 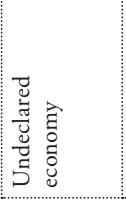 & 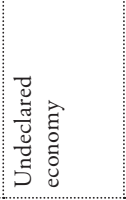 & 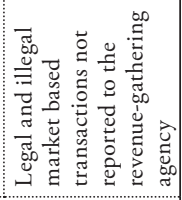 \\
\hline 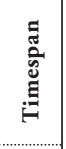 & 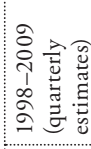 & 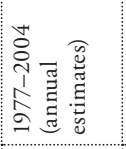 & 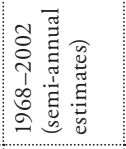 & 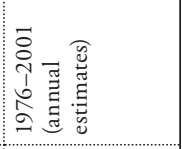 \\
\hline 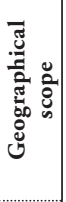 & Uू & 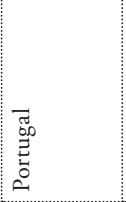 & 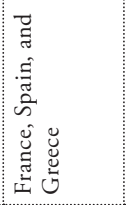 & U⿺ \\
\hline 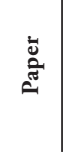 & 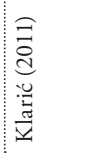 & 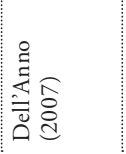 & 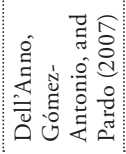 & 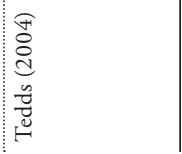 \\
\hline
\end{tabular}




\section{Appendix 2: Stationarity Tests}

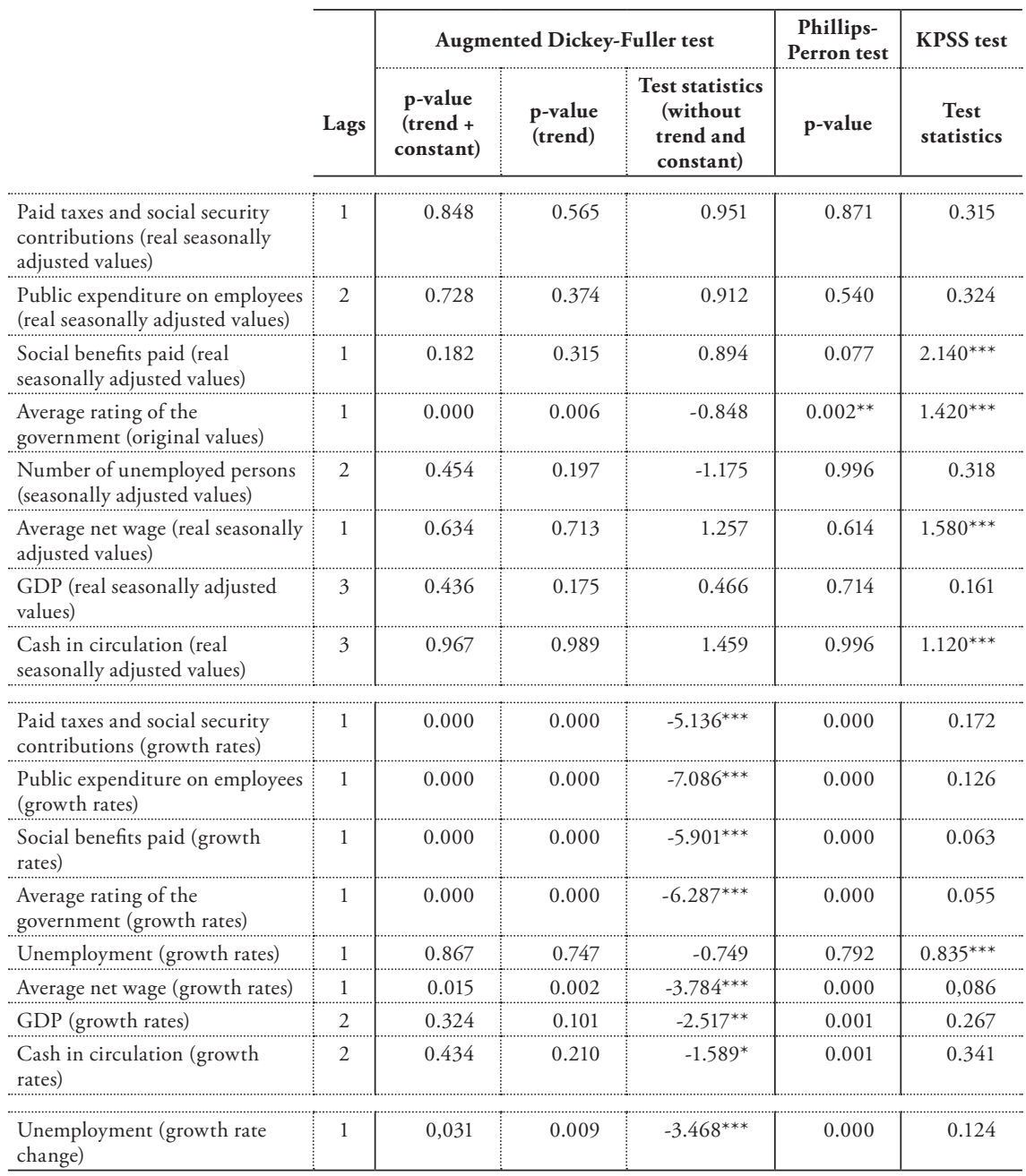

Note: The zero hypothesis of Dickey-Fuller and Phillips-Perron tests assumes non-stationary of the observed variable, while the opposite is the case for the KPSS test.

Source: Author's calculations. 


\section{Appendix 3: The Procedure for Transforming the Results of the MIMIC Modeling and Labor Input Method into Numerical Values of Value Added by Undeclared Economy}

This section explains the process of obtaining quarterly added values of undeclared activities in a situation where the latent variable in the MIMIC model is defined in terms of growth rates and the external estimate is given on an annual basis. If $X_{q 1}-X_{q 4}$ are the values of quarterly value added by undeclared activities, then it must be:

$X_{q 1}+X_{q 2}+X_{q 3}+X_{q 4}=Y$,

where $Y$ denotes the external value for the accompanying year. Since in our case the MIMIC analysis gives quarterly growth rates $\Delta X_{t}$, the equation (A3-1) can be expressed as a system with $X_{q 1}$ as the only unknown variable after applying an iterative procedure. For instance, from the definition of $\Delta X_{q 2}$ :

$\Delta X_{q 2}=\frac{X_{q 2}-X_{q 1}}{X_{q 1}}$,

we can see that $X_{q 2}$ can be written as follows:

$X_{q 2}=\Delta X_{q 2} * X_{q 1}+X_{q 1}=X_{q 1}\left(\Delta X_{q 2}+1\right)$.

Similarly, it is easy to see that $X_{q 3}$ can be expressed as:

$X_{q 3}=\Delta X_{q 3} * X_{q 2}+X_{q 2}=X_{q 2}\left(\Delta X_{q 3}+1\right)$.

Replacing the value for $X_{q 2}$ from (A3-3) into (A3-4) gives:

$X_{q 3}=X_{q 1}\left(\Delta X_{q 2}+1\right)\left(\Delta X_{q 3}+1\right)$.

The same procedure applied to the variable $X_{q 4}$ gives:

$$
\begin{aligned}
X_{q 4} & =\Delta X_{q 4} * X_{q 3}+X_{q 3}=X_{q 3}\left(\Delta X_{q 4}+1\right) \\
& =X_{q 1}\left(\Delta X_{q 2}+1\right)\left(\Delta X_{q 3}+1\right)\left(\Delta X_{q 4}+1\right) .
\end{aligned}
$$


Replacing the values for $X_{q 2}, X_{q 3}$, and $X_{q 4}$ from (A3-3), (A3-5), and (A3-6) into (A3-1) gives:

$$
\begin{gathered}
X_{q 1}+X_{q 1}\left(\Delta X_{q 2}+1\right)+X_{q 1}\left(\Delta X_{q 2}+1\right)\left(\Delta X_{q 3}+1\right)+ \\
+X_{q 1}\left(\Delta X_{q 2}+1\right)\left(\Delta X_{q 3}+1\right)\left(\Delta X_{q 4}+1\right)=Y
\end{gathered} .
$$

Since $X_{q 1}$ is present in every single multiplicative factor on the left-hand side, the equation (A3-7) can be rewritten as:

$$
\begin{aligned}
& X_{q 1}\left[1+\Delta X_{q 2}+1+\left(\Delta X_{q 2}+1\right)\left(\Delta X_{q 3}+1\right)+\right. \\
& \left.\quad+\left(\Delta X_{q 2}+1\right)\left(\Delta X_{q 3}+1\right)\left(\Delta X_{q 4}+1\right)\right]=Y .
\end{aligned}
$$

The formula for value added by undeclared activities in the first quarter of the analyzed year is then attained after dividing both sides of the equation (A3-8) by the expression in parenthesis:

$$
X_{q 1}=\frac{Y}{2+\Delta X_{q 2}+\left(\Delta X_{q 2}+1\right)\left(\Delta X_{q 3}+1\right)+\left(\Delta X_{q 2}+1\right)\left(\Delta X_{q 3}+1\right)\left(\Delta X_{q 4}+1\right)} \text {. }
$$

Once the value of $X_{q 1}$ is known, all other values can be calculated from the definition of growth rates (as illustrated in the equation [A3-2] for $\Delta X_{q 2}$ ). 


\section{Appendix 4: Value Added by the Undeclared Economy in Croatia for the 2004- 2017 Period, Quarterly Estimates}

\begin{tabular}{|c|c|c|c|}
\hline & $\begin{array}{c}\text { Value added in HRK million } \\
\text { (nominal values) }\end{array}$ & $\begin{array}{c}\text { Value added in HRK million } \\
\text { (real values) }\end{array}$ & $\begin{array}{c}\text { Undeclared economy as \% } \\
\text { of the official GDP }\end{array}$ \\
\hline $2004 \mathrm{q} 1$ & $4,480.54$ & $5,629.95$ & 7.86 \\
\hline $2004 \mathrm{q} 2$ & $4,924.65$ & $6,088.08$ & 7.85 \\
\hline $2004 \mathrm{q} 3$ & $5,327.55$ & $6,420.36$ & 7.80 \\
\hline $2004 q 4$ & $4,901.34$ & $5,937.06$ & 7.80 \\
\hline $2005 \mathrm{q} 1$ & $4,676.66$ & $5,663.73$ & 7.75 \\
\hline $2005 q 2$ & $5,283.24$ & $6,335.66$ & 7.79 \\
\hline $2005 q 3$ & $5,739.47$ & $6,692.64$ & 7.76 \\
\hline $2005 q 4$ & $5,195.00$ & $6,087.49$ & 7.63 \\
\hline $2006 q 1$ & $5,077.95$ & $5,913.19$ & 7.61 \\
\hline $2006 \mathrm{q} 2$ & $5,510.91$ & $6,318.19$ & 7.49 \\
\hline $2006 \mathrm{q} 3$ & $5,927.78$ & $6,653.03$ & 7.37 \\
\hline $2006 q 4$ & $5,501.37$ & $6,226.51$ & 7.46 \\
\hline $2007 \mathrm{q} 1$ & $5,420.69$ & $6,116.44$ & 7.37 \\
\hline $2007 q 2$ & $5,919.73$ & $6,544.68$ & 7.31 \\
\hline $2007 q 3$ & $6,370.07$ & $6,858.68$ & 7.29 \\
\hline $2007 q 4$ & $5,847.03$ & $6,285.91$ & 7.27 \\
\hline $2008 \mathrm{q} 1$ & $5,886.06$ & $6,298.01$ & 7.34 \\
\hline $2008 \mathrm{q} 2$ & $6,433.99$ & $6,741.04$ & 7.32 \\
\hline $2008 \mathrm{q} 3$ & $6,829.45$ & $6,889.39$ & 7.22 \\
\hline $2008 \mathrm{q} 4$ & $6,149.11$ & $6,290.97$ & 7.23 \\
\hline $2009 \mathrm{q} 1$ & $5,752.91$ & $5,877.03$ & 7.49 \\
\hline $2009 q 2$ & $6,225.34$ & $6,276.31$ & 7.42 \\
\hline $2009 q 3$ & $6,605.24$ & $6,599.89$ & 7.49 \\
\hline $2009 q 4$ & $6,165.81$ & $6,199.22$ & 7.50 \\
\hline $2010 \mathrm{q} 1$ & $5,645.94$ & $5,721.75$ & 7.52 \\
\hline $2010 q 2$ & $6,218.89$ & $6,222.37$ & 7.56 \\
\hline $2010 \mathrm{q} 3$ & $6,794.34$ & $6,739.08$ & 7.58 \\
\hline $2010 q 4$ & $6,174.50$ & $6,149.97$ & 7.54 \\
\hline $2011 \mathrm{q} 1$ & $5,702.12$ & $5,645.22$ & 7.60 \\
\hline $2011 \mathrm{q} 2$ & $6,309.72$ & $6,221.07$ & 7.49 \\
\hline $2011 \mathrm{q} 3$ & $6,871.32$ & $6,724.13$ & 7.56 \\
\hline $2011 \mathrm{q} 4$ & $6,265.79$ & $6,147.03$ & 7.54 \\
\hline $2012 \mathrm{q} 1$ & $5,673.43$ & $5,571.91$ & 7.59 \\
\hline $2012 q 2$ & $6,321.97$ & $6,129.09$ & 7.60 \\
\hline $2012 q 3$ & $6,864.41$ & $6,624.28$ & 7.59 \\
\hline $2012 q 4$ & $6,189.27$ & $5,936.15$ & 7.50 \\
\hline
\end{tabular}




\begin{tabular}{|c|c|c|c|}
\hline & $\begin{array}{c}\begin{array}{c}\text { Value added in HRK million } \\
\text { (nominal values) }\end{array} \\
\end{array}$ & $\begin{array}{c}\text { Value added in HRK million } \\
\text { (real values) }\end{array}$ & $\begin{array}{c}\text { Undeclared economy as \% } \\
\text { of the official GDP }\end{array}$ \\
\hline $2013 q 1$ & $5,727.61$ & $5,511.61$ & 7.64 \\
\hline $2013 q 2$ & $6,436.22$ & $6,162.95$ & 7.67 \\
\hline $2013 q 3$ & $6,944.41$ & $6,671.67$ & 7.68 \\
\hline $2013 q 4$ & $6,344.70$ & $6,112.84$ & 7.73 \\
\hline $2014 q 1$ & $5,646.13$ & $5,454.67$ & 7.65 \\
\hline $2014 q 2$ & $6,460.94$ & $6,201.82$ & 7.75 \\
\hline $2014 q 3$ & $7,156.20$ & $6,843.85$ & 7.85 \\
\hline $2014 q 4$ & $6,528.89$ & $6,268.01$ & 7.87 \\
\hline $2015 q 1$ & $5,853.97$ & $5,645.43$ & 7.81 \\
\hline $2015 q 2$ & $6,668.20$ & $6,390.53$ & 7.84 \\
\hline $2015 q 3$ & $7,353.04$ & $7,045.77$ & 7.79 \\
\hline $2015 q 4$ & $6,603.03$ & $6,351.33$ & 7.81 \\
\hline $2016 q 1$ & $6,025.73$ & $5,818.70$ & 7.79 \\
\hline $2016 q 2$ & $6,814.51$ & $6,543.16$ & 7.80 \\
\hline $2016 q 3$ & $7,542.32$ & $7,226.87$ & 7.76 \\
\hline $2016 q 4$ & $6,753.47$ & $6,498.16$ & 7.72 \\
\hline $2017 q 1$ & $6,241.37$ & $6,002.24$ & 7.83 \\
\hline $2017 q 2$ & $7,084.26$ & $6,739.02$ & 7.80 \\
\hline $2017 q 3$ & $7,931.75$ & $7,485.82$ & 7.77 \\
\hline $2017 q 4$ & $7,004.58$ & $6,629.42$ & 7.72 \\
\hline
\end{tabular}

Source: Author's calculations. 


\section{Literature}

Abdixhiku, L., Krasniqi, B., Pugh, G., \& Hashi, I. (2017). Firm-level determinants of tax evasion in transition economies. Economic Systems, 41(3), 354-366. doi: https://doi.org/10.1016/j.ecosys.2016.12.004

Andrews, D., Caldera Sánchez, A., \& Johansson, Å. (2011). Towards a better understanding of the informal economy. OECD Economics Department Working Paper No. 873. doi: https://doi.org/10.1787/5kgb1mf88x28-en

Barbosa, E., Pereira, S., \& Brandão, E. (2013). The shadow economy in Portugal: An analysis using the MIMIC model. Working Papers (FEP) - Universidade Do Porto No. 514, 1-48.

Baric, M., \& Williams, C. C. (2013). Tackling the undeclared economy in Croatia. South-Eastern Europe Journal of Economics, 1, 7-36.

Bourhaba, O., \& Mama, H. (2016). An estimation of the informal economy in Morocco. International Journal of Economics and Finance, 8(9), 140-147. doi: https://doi.org/10.5539/ijef.v8n9p140

Breusch, T. (2005a). Estimating the underground economy using MIMIC Models. Canberra: The Australian National University.

Breusch, T. (2005b). The Canadian underground economy: An examination of Giles and Tedds. Canadian Tax Journal, 53(2), 367-391.

Buehn, A., \& Schneider, F. (2012). Shadow economies around the world: Novel insights, accepted knowledge, and new estimates. International Tax and Public Finance, 19(1), 139-171. doi: https://doi.org/10.1007/s10797-011-9187-7

Cagan, P. (1958). The demand for currency relative to the total money supply. Journal of Political Economy, 66(4), 303-328.

Carr, M., \& Chen, M. A. (2001). Globalization and the informal economy: How global trade and investment impact on the working poor. Geneva: International Labour Organisation. 
Castells, M., \& Portes, A. (1989). World underneath: The origins, dynamics, and effects of the informal economy. In A. Portes, M. Castells, and L. A. Benton (Eds.), The informal economy; studies in advanced and less developed countries (pp. 11-37). Baltimore, MD: The Johns Hopkins University Press.

Chen, M. A. (2005). Rethinking the informal economy: Linkages with the formal economy and the formal regulatory environment. WIDER Working Paper 10/2005.

Croatian Employment Service (CES). (2018). Registrirana nezaposlenost. Retrieved from: http://statistika.hzz.hr/statistika.aspx?tipIzvjestaja=1.

Croatian National Bank (CNB). (2018a). Bilanca HNB-a. Retrieved from: https://www.hnb.hr/statistika/statisticki-podaci/financijski-sektor/sredisnjabanka-hnb/bilanca-hnb-a.

Croatian National Bank (CNB). (2018b). Nefinancijski računi opće države. Retrieved from: https://www.hnb.hr/statistika/statisticki-podaci/opca-drzava/ nefinancijski-racuni-opce-drzave.

Davis, M. (2006). Planet of slums. London: Verso.

de Soto, H. (1989). The other path; The invisible revolution in the Third World. New York, NY: Harper and Row.

Dell'Anno, R. (2003). Estimating the shadow economy in Italy: A structural equation approach. University of Aarhus Working Paper No. 2003-07.

Dell'Anno, R. (2007). The shadow economy in Portugal: An analysis with the MIMIC approach. Journal of Applied Economics, 10(2), 253-277.

Dell'Anno, R., Davidescu, A. A., \& Balele, N. P. (2018). Estimating shadow economy in Tanzania: An analysis with the mimic approach. Journal of Economic Studies, 45(1), 100-113. doi: https://doi.org/10.1108/JES-11-2016-0240

Dell'Anno, R., Gómez-Antonio, M., \& Pardo, A. (2007). The shadow economy in three Mediterranean countries: France, Spain and Greece. A MIMIC approach. Empirical Economics, 33(1), 51-84. doi: https://doi.org/10.1007/s00181-0060084-3 
Elgin, C., \& Öztunali, O. (2012). Shadow economies around the world: Model based estimates. Bogazici University Working Papers 2012/05.

Eurofound. (2008). Measures to tackle undeclared work in the European Union. Dublin: The European Foundation for the Improvement of Living and Working Conditions (Eurofound).

Eurofound. (2013). Tackling undeclared work in 27 European Union member states and Norway: Approaches and measures since 2008. Dublin: The European Foundation for the Improvement of Living and Working Conditions (Eurofound).

European Commission. (2007). Stepping up the fight against undeclared work (COM (2007) 628 final). Brussels: European Commission.

European Commission. (2009). Study on indirect measurement methods for undeclared work in the EU. Brussels: European Commission, Directorate-General for Employment, Social Affairs and Equal Opportunities.

European Commission. (2014). Special Eurobarometer 402. Undeclared work in the European Union. Brussels: European Commission.

European Commission. (2016a). European Platform tackling undeclared work: Member state factsheets and synthesis report. Brussels: European Commission, Directorate-General for Employment, Social Affairs and Inclusion.

European Commission. (2016b). Launch of the European Platform tackling undeclared work. Retrieved from: http://ec.europa.eu/social/main.jsp?langId=hr\&catId=706\&eve ntsId=1093\&furtherEvents=yes.

European Commission. (2017). An evaluation of the scale of undeclared work in the European Union and its structural determinants: Estimates using the labour input method. Luxembourg: European Commission.

Eurostat. (2018). National accounts. Retrieved from: http://ec.europa.eu/eurostat/ web/national-accounts/data/database.

Feige, E. L. (1989). The meaning and measurement of the underground economy. In E. L. Feige (Ed.), The underground economies (pp. 13-56). New York, NY: Cambridge University Press. 
Feld, L. P., \& Larsen, C. (2005). Black activities in Germany in 2001 and in 2004. A comparison based on survey data. Copenhagen: Rockwool Foundation Research Unit.

Franic, J., \& Williams, C. C. (2014). Undeclared work in Croatia: A baseline assessment, GREY Working Paper No. 2. Sheffield: Sheffield University Management School. doi: https://doi.org/10.2139/ssrn.2435142

Franic, J., \& Williams, C. C. (2017). Illegitimate economic practices in Croatia. Findings from a representative survey of 2,000 citizens, GREY Working Paper No. 9. Sheffield: Sheffield University Management School. doi: http://dx.doi. org/10.2139/ssrn.2932315

Hart, K. (1973). Informal income opportunities and urban employment in Ghana. The Journal of Modern African Studies, 11(1), 61-89.

Hassan, M., \& Schneider, F. (2016). Modelling the Egyptian shadow economy. A MIMIC model and a currency demand approach. Journal of Economics and Political Economy, 3(2), 309-339.

Hazans, M. (2005). Latvia: Working too hard? In D. Vaughan-Whitehead (Ed.), Working and employment conditions in new EU member states - convergence or diversity? (pp. 161-212). Geneva: ILO-EC.

Hudson, J., Williams, C., Orviska, M., \& Nadin, S. (2012). Evaluating the impact of the informal economy on businesses in South East Europe: Some lessons from the 2009 World Bank Enterprise Survey, South East European Journal of Economics and Business, 7(1), 99-110. doi: https:/doi.org/10.2478/v10033-012-0010-x

International Labour Organization (ILO). (1972). Employment, incomes and equality; A strategy for increasing productive employment in Kenya. Geneva: International Labour Organization.

International Labour Organization (ILO). (1993). Statistics of employment in the informal sector. Fifteenth International Conference of Labour Statisticians. Geneva: International Labour Organization. 
International Labour Organization (ILO). (1999). Decent work and protection for all priority of the Americas. Fourteenth regional meeting of ILO American member states, Report of the Director General. Lima: International Labour Organization.

International Labour Organization (ILO). (2002). Decent work and informal economy. International Labour Conference Report. Geneva: International Labour Organization.

International Labour Organization (ILO). (2013). Measuring informality: A statistical manual on the informal sector and informal employment. Geneva: International Labour Organisation.

Istituto nazionale di statistica. (1993). The underground economy in Italian economic accounts. Rome: Istituto nazionale di statistica.

Johnson, S., Kaufmann, D., \& Shleifer, A. (1997). The unofficial economy in transition. Brookings Papers on Economic Activity, 2, 159-239.

Kaufmann, D., \& Kaliberda, A. (1996). Integrating the unofficial economy into the dynamics of post-socialist economies: A framework of analysis and evidence. Policy Research Working Paper 1691. Washington, DC: The World Bank.

Klarić, V. (2011). Estimating the size of non-observed economy in Croatia using the MIMIC approach. Financial Theory and Practice, 35(1), 59-90.

Kline, R. B. (2011). Principles and practice of structural equation modeling ( $3^{\text {rd }}$ ed.). New York, NY: The Guilford Press.

Krasniqi, B., \& Williams, C. (2017). Explaining individual- and country-level variations in unregistered employment using a multi-level model: Evidence from 35 Eurasian countries. South East European Journal of Economics and Business, 12(2), 61-72. doi: https:/doi.org/10.1515/jeb-2017-0017

Lacko, M. (1999). Do power consumption data tell the story? - Electricity intensity and hidden economy in post-socialist countries. Budapest Working Papers on the Labour Market BWP - 1999/2. Budapest: The Institute of Economics, Hungarian Academy of Sciences. 
Lazar, D. T., Moldovan, B. A., \& Pavel, A. (2008). Underground economy's measurement methods. Transylvanian Review of Administrative Sciences, 4(23), $43-58$.

Lewis, W. A. (1954). Economic development with unlimited supplies of labour. Manchester School of Economic and Social Studies, 22(2), 139-191. doi: https:// doi.org/10.1111/j.1467-9957.1954.tb00021.x

Lovrinčević, Ž., Mikulić, D., \& Nagyszombaty, A. G. (2011). Unofficial economy in Croatia and the impact of the economic recession on the unofficial economy. In Conference proceedings of the $9^{\text {th }}$ international conference "Challenges of Europe: Growth and competitiveness - reversing the trends" (pp. 479-508). Split: Faculty of Economics, University of Split.

Madžarević, S., \& Mikulić, D. (1997). Mjerenje neslužbenog gospodarstva sustavom nacionalnih računa [Measuring the unofficial economy with the system of national accounts]. Financijska praksa, 21(1-2), 141-156.

Maloney, W. F. (2004). Informality revisited. World Development, 32(7), 11591178 .

Medina, L., \& Schneider, F. (2017). Shadow economies around the world: New results for 158 countries over 1991-2015. CESifo Working Paper No. 6430. Munich: Center for Economic Studies \& IFO Institute.

Ministry of Labour and Pension System (2014). 2014. - godina borbe protiv rada "na crno" [2014 - the year of the fight against undeclared work]. Retrieved from: http://www.mrms.hr/2014-godina-borbe-protiv-rada-na-crno/.

Nastav, B., \& Bojnec, Š. (2007). The shadow economy in Bosnia and Herzegovina, Croatia, and Slovenia. The labour approach. Eastern European Economics, 45(1), $29-58$.

Nchor, D., \& Adamec, V. (2015). Unofficial economy estimation by the MIMIC model: The case of Kenya, Namibia, Ghana and Nigeria. Acta Universitatis Agriculturae et Silviculturae Mendelianae Brunensis, 63(6), 2043-2049. doi: https://doi.org/10.11118/actaun201563062043 
OECD (2002). Measuring the non-observed economy. A handbook. Paris: OECD.

Pedersen, S. (2003). The shadow economy in Germany, Great Britain and Scandinavia. A measurement based on questionnaire surveys. Copenhagen: The Rockwool Foundation Research Unit.

Rakowski, C. A. (1994). Convergence and divergence in the informal sector debate: A focus on Latin America, 1984-92. World Development, 22(4), 501516. doi: https://doi.org/10.1016/0305-750X(94)90107-4

Raykov, T., \& Marcoulides, G. A. (2006). A first course in structural equation modeling ( $2^{\text {nd }}$ ed.). Mahwah, NJ: Lawrence Erlbaum Associates, Inc.

Round, J., Williams, C. C., \& Rodgers, P. (2008). Corruption in the postSoviet workplace: The experiences of recent graduates in contemporary Ukraine. Work, Employment \& Society, 22(1), 149-166. doi: https://doi. org/10.1177/0950017007087421

Ruge, M. (2010). Determinants and size of the shadow economy - A structural equation model. International Economic Journal, 24(4), 511-523. doi: https:// doi.org/10.1080/10168737.2010.525988

Schneider, F. (2012). Size and development of the shadow economy of 31 European and 5 other OECD countries from 2003 to 2012: Some new facts. Unpublished paper. Retrieved from: http://www.seipa.edu.pl/s/p/artykuly/93/931/Shadow\%20 Economy\%20up\%20to\%202012.pdf.

Schneider, F. (2013). The shadow economy in Europe, 2013. A.T. Kearney Korea and Visa Europe. Retreived from: https://www.atkearney.com/ documents/10192/1743816/The+Shadow+Economy+in+Europe+2013.pdf.

Schneider, F. (2016a). Estimating the size of the shadow economies of highlydeveloped countries: Selected new results. CESifo DICE Report, 14(4), 44-53.

Schneider, F. (2016b). Shadow economy in Austria - The latest developments up to 2016. Linz: Johannes Kepler University Linz. 
Schneider, F., \& Buehn, A. (2016). Estimating the size of the shadow economy: Methods, problems and open questions. IZA Discussion Paper No. 9820. Bonn: The Institute for the Study of Labor (IZA).

Schneider, F., Buehn, A., \& Montenegro, C. (2010). Shadow economies all over the world. New estimates for 162 countries from 1999 to 2007. Policy Research Working Paper No. 5356. Washington, DC: World Bank Group.

Sedlenieks, K. (2003). Cash in an envelope: Corruption and tax avoidance as an economic strategy in contemporary Riga. In K.-O. Arnstberg and T. Boren (Eds.), Everyday economy in Russia, Poland \& Latvia (pp. 37-52). Stockholm: Almqvist and Wiksell.

Sethuraman, S. V. (1976). The urban informal sector: Concept, measurement and policy. International Labour Review, 114(1), 69-81.

Švec, M. (2009). Siva ekonomija u Hrvatskoj. Financijska teorija i praksa, 33(4), $415-444$.

Tanzi, V. (1980). The underground economy in the United States: Estimates and implications. Banca Nazionale Del Lavoro Quarterly Review, 135(4), 427-453.

Tedds, L. (2004). The underground economy in Canada. Hamilton: McMaster University.

Tokman, V. E. (1978). An exploration into the nature of informal - formal sector relationship. World Development, 6(9/10), 1065-1075. doi: https://doi. org/10.1016/0305-750X(78)90063-3

Torgler, B. (2011). Tax morale, Eastern Europe and European enlargement. The World Bank, Policy Research Working Paper No. 5911.

Williams, C. C., \& Franic, J. (2017). Tackling the illegitimate under-reporting of salaries in Southeast Europe: Some lessons from a 2015 survey in Bulgaria, Croatia and FYR Macedonia. Eastern Journal of European Studies, 8(1), 5-28.

Woolfson, C. (2007). Pushing the envelope: The "informalization" of labour in post-communist new EU member states. Work, Employment \& Society, 21(3), $551-564$. 